\title{
ANALISIS KOMPILASI HUKUM EKONOMI SYARIAH TERHADAP PRAKTIK MUAMALAH PADA PEMBELIAN BUAH MANGGA DENGAN SISTEM TEBAS
}

\author{
Anik Nur Ria \\ IAIN Ponorogo \\ aniknurria22@gmail.com
}

\begin{abstract}
Abstrak: Manusia tidak lepas dari aktivitas jual beli. Jual beli adalah kegiatan sosial yang memberikan timbal balik. Dalam fiqh ada larangan jual beli dengan sistem tebas. Namun, ada ulama yang memperbolehkan jual beli tebas, dengan mengikuti beberapa syarat. Untuk itu, penelitian ini bertujuan untuk mengungkap jual beli sistem tebas yang diperbolehkan oleh ulama dengan menjelaskan dasar hukum, syarat, dan kompilasi transaksi jual beli sistem tebas. Penelitian ini menggunakan pendekatan kualitatif dengan analisis kompilasi hukum ekonomi syariah tentang praktek muamalah dalam pembelian mangga dengan sistem tebas.
\end{abstract}

Kata Kunci: Jual Beli, Sistem Tebas, Hukum Jual Beli

\section{Pendahuluan}

Dalam memenuhi kebutuhan hidup, manusia diberi kebebasan oleh Allah subhanahu wa ta'ala untuk memenuhi kebutuhannya. Manusia diperbolehkan untuk mengambil manfaat dari segala apa yang ada di muka bumi ini yang menjadi ciptaan Allah. Akan tetapi seperti halnya ciptaan, pastilah memiliki batasan pengetahuan terhadap apa yang menjadi ciptaan-Nya. Dan itulah yang menjadi keharusan mutlak bahwa 
manusia harus ber-Islam (tunduk, patuh) terhadap kekuasaan-Nya yang telah dijelaskan di dalam Al-Qur'an dan As-Sunnah.

Selain membuat manusia harus patuh kepada kekuasaan-Nya, manusia harus patuh terhadap segala bentuk ketetapan-ketetapan yang dibuat oleh-Nya. Bentuk ketetapan Allah yang ada di dalam Al-Qur'an dan Sunnah juga tidak hanya mengatur tentang bentuk hubungan antara Allah dengan ciptaan-Nya, akan tetapi juga mengatur tentang bagaimana hubungan manusia dengan sesamanya, karena sudah dijelaskan bahwa manusia tidak bisa hidup seorang diri, dan harus bersosialisasi antar sesamanya.

Hubungan manusia dengan manusia inilah yang menjadi unsur penting dalam memenuhi kebutuhan hidup manusia itu sendiri. Seperti yang dijelaskan diatas bahwa Allah memberikan kebebasan terhadap hamba-Nya dalam memenuhi kebutuhan hidupnya, akan tetapi terdapat batasan yang dimiliki oleh manusia sebagai makhluk ciptaan-Nya. Bentuk batasan yang ada di dalam Al-Qur'an dan Sunnah menjadi dasar dalam bermuamalah. Maka dari itu negara memberikan fasilitas yaitu dengan menjadikan hukum Islam yang berasal dari Al-Qur'an dan Sunnah dikodifikasi menjadi sebuah hukum positif di Indonesia melalui terbentuknya kompilasi hukum ekonomi.

Bentuk muamalah yang akan dibahas berkaitan dengan jual beli.khususnya jual beli buah mangga dengan sistem tebas. Pembahasan ini sangat penting karena di dalam masyarakat masih banyak penerapan praktik jual beli seperti ini sehingga perlu adanya penerapan perspektif kompilasi hukum ekonomi syariah terkait praktik jual beli seperti hal ini.

\section{Pengertian Jual Beli}

Dalam istilah fiqh jual beli atau perdagangan disebut dengan $a l-b a^{\prime} i$ sedangkan dalam terminologi berarti menjual atau mengganti. Menurut Wahbah al-Zuhaily adalah menukar sesuatu dengan sesuatu yang lain. dalam arab kata al-ba'i digunakan untuk pengertian lawan dari kata al-ba'i yaitu al-syira' (beli). Dengan demikian kata al-ba'i berarti jual, sekaligus beli. ${ }^{1}$

Secara terminologi, terdapat beberapa definisi jual beli yang dikemukakan para ulama fiqh, baik subtansi dan tujuan masing-masing definisi sama. Sayyid Sabiq, mendefinisikannya dengan:

$$
\text { مبادلة مال بمال على سبيل التراضى, او نقل ملك بعوض على الوجه المأذون فيه }
$$

1 Jamaluddin Jamaluddin, "Konsep Dasar Muamalah \& Etika Jual Beli (Al-Ba’i) Perspektif Islam," Jurnal Pemikiran Keislaman, 2017, 
"Tual beli ialah pertukaran harta dengan harta atas dasar saling merelakan". atau "memindabkan milik dengan ganti yang dapat dibenarkan".

\section{Rukun Jual Beli}

Dalam jual beli terdapat empat rukun, yaitu: ijab qabul (sighab), penjual ( $b a^{\prime} \imath$ ), pembeli (musytar), dan objek yang diperjual belikan (mabi). Menurut Madzhab Hanafi, rukun jual beli hanya satu yaitu, ijab dan qabul (sighab). Sedangkan penjual dan pembeli, barangnya hanya sebagai akibat dari rukun ijab dan qabul (sighah). ${ }^{2}$

Berikut adalah paparan rukun jual beli: Ijab dan qabul (sighah), adalah ucapan yang menunjukkan bahwa penjual dan pembeli sama-sama rela (taradhin). ijab adalah ucapaan dari penjual sebagai tanda kerelaannya untuk menjual barangnya. qabul adalah ucapan dari pembeli sebagai tanda persetujuan untuk membeli barang tersebut.

Penjual dan pembeli (ba'i wal musytari), terdapat syarat bagi penjual, diantaranya: sehat akal dan sudah dewasa dalam melakukan jual beli, dalam hal kedewasaan, kompilasi hukum ekonomi islam memberikan batas usia minimal 18 tahun atau sudah menikah.

Barang (mabi), harus memenuhi kriteria, antara lain: berupa barang yang berwujud saat akad dilangsungkan, barang yang dijual belikan berupa harta (mal) atau dapat bermanfaat dan memberi manfaat, barang milik penjual saat terjadi akad, barang dapat diserah terimakan, barang diketahui oleh penjual dan pembeli, dan tidak sah apabila barang masih berupa bunga di atas pohon.

\section{Dasar Hukum Jual Beli Berdasarkan Sunnah Rasulullah}

Hadis yang diriwayatkan oleh Rifa'ah ibn Rafi':

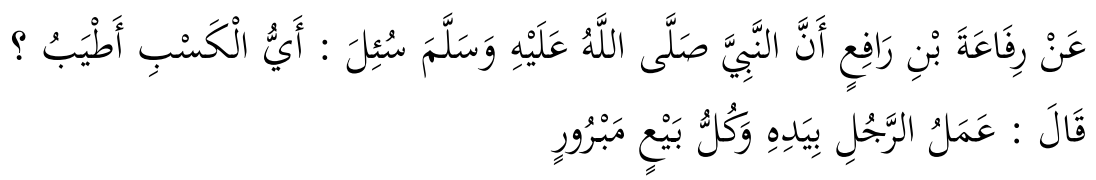

"Rifa'ab bin Rafi'i berkata bahwa Nabi SÄW ditanya, "apa mata pencaharian yang paling baik? "Nabi menjawab, "usaha tangan manusia sendiri dan setiap jual beli yang diberkati. "(diriwayatkan oleh Bazzar dan disabkan oleh Hakim)

Hadis yang diriwayatkan oleh Al-Baihaqi, Ibn Majah dan Ibn Hibban, Rasulullah menyatakan:

\footnotetext{
${ }^{2}$ M Pudjiraharjo and Nur Faizin Muhith, Fikih Muamalab Ekonomi Syariah (Universitas Brawijaya Press, 2019).
} 
"Tual beli itu didasarkan atas suka sama suka"

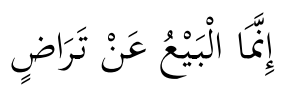

\section{Dasar Hukum Jual Beli}

Dalam jual beli di dalam Al-Qur'an diperbolehkan, yang menjadi dasarnya adalah surat al-Baqarah ayat 275. Allah SW'T berfirman:

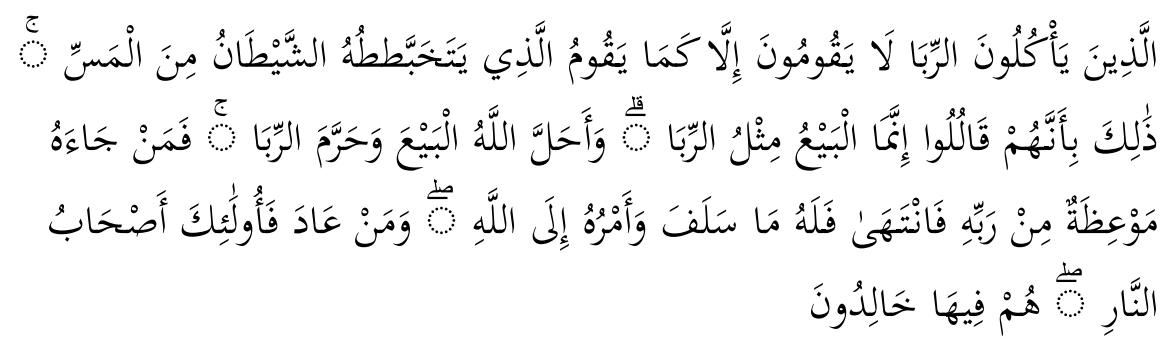

"Orang-orang yang memakan riba tidak dapat berdiri, melainkan seperti berdirinya orang yang kemasukan setan karena gila. Yang demikian itu karena mereka berkata babwa jual beli sama dengan riba. Padabal, Allah telah menghalalkan jual-beli dan mengharamkan riba. Barang siapa mendapat peringatan dari Tubannya, lalu dia berbenti, maka apa yang telah diperolebnya dabulu menjadi miliknya dan urusannya (terserah) kepada Allah. Barang siapa mengulangi, maka mereka itu penghuni neraka, mereka kekal di dalamnya." (QS. Al-Baqarah: 275).

Dalam ayat Al-Qur'an di atas menekankan bahwa Allah menghalalkan jual beli dan mengharamkan riba, inilah yang menjadi dasar bahwa praktik jual beli secara umum diperbolehkan selama tidak ada unsur riba di dalamnya. Sebagaimana hukum jual beli berdasarkan hadis yang diriwayatkan Bazzar dan disahkan oleh hakim. Dalam hadis tersebut terlihat jelas bahwa nabi memposisikan praktik jual beli sebagai usaha atau pekerjaan yang paling baik. Dan inilah yang menjadi dasar hadis bahwa jual beli diperbolehkan dalam Islam. Berkaitan dengan dasar jual beli tersebut mengisyaratkan bahwa jual beli yang dilakukan oleh setiap manusia diperbolehkan dengan ketentuan-ketentuan yang telah ditetapkan oleh syariat.

Jual beli halal: hukum jual beli adalah mubah atau diperbolehkan. Al-Imam Asy-Syafi'I menegaskan bahwa dasar hukum jual beli secara keseluruhan adalah mubah, yaitu dengan adanya ridha dari kedua belah

\footnotetext{
${ }^{3}$ Abdul Rahman Ghazaly, Ghufron Ihsan, and Sapiudin Shidiq, Fiqh Muamalat (Jakarta: Fakultas Ilmu Tarbiyah dan Keguruan UIN Syarif Hidayatullah, 2016, 2016).

${ }^{4}$ RI Kementerian Agama, Al-Qur'an Terjemahan, Al-Qur'an Terjemahan, 2007.
} 
pihak. Namun kehalalan barang akan berubah menjadi haram apabila terjadi sesuatu hal. Misalnya, apabila jual beli itu dilarang oleh Rasulullah SAW atau yang termasuk dalam larangan jual beli.

Jual beli haram: haram yang terkait dengan akad yaitu yang pertama barang yang melanggar syariah mislanya objek akad tidak memenuhi syarat dan ketentuan dalam akad, seperti barang tersebut najis, tidak memberikan manfaat, atau barang tersebut tidak diserahkan. Yang kedua akad melanggar syariah, karena terdapat unsur riba didalamnya antara lain bai'ul 'inah, al-murabanah, al - mubaqalah, al - araya, al - 'urbun, baiul akli' bil kali', dan lainnya. Sedangkan yang termasuk didalam unsur gharar antara lain, jual beli hewan masih didalam kandungan, jual beli buah yang belum matang, bai'us-sinin, jual beli ikan di dalam air, jual beli budak yang kabur dari tuannya, jual-beli susu yang masih didalam tubuh hewan, jual beli wol yang masih melakat pada kambing, dan baiuts-tsuyya. ${ }^{5}$

Haram yang berkaitan dengan hal hal diluar akad, yang pertama: dharah mutlak, misalnya jual beli buah yang akan dijadikan khamar, jual beli an-najsy, talaqqi ar-rukban, bai'u hadhirun li badiyyin. Yang kedua: melanggar larangan agama misalnya jual beli yang dilakukan pada saat terdengar azan sholat Jumat.

\section{Rukun dan Syarat Jual Beli (Ba'i) Menurut KHEI}

Berkaitan dengan jual beli buah mangga dengan sistem tebas dalam perspektif KHI, dapat dianalisis dari pemenuhan rukun-rukun sesuai KHI. ${ }^{6}$ Dalam buku II bab IV bagian pertama pasal 56 menjelaskan bahwa: Rukun bai' terdiri atas: pihak-pihak yang terlibat yaitu penjual dan pembeli, obyek; yaitu harga dan barang, dan kesepakatan, persetujuan dua belah pihak yang telah melakukan akad. Dalam hal pihak-pihak yang bertransaksi dalam praktik jual beli buah mangga dengan sistem tebas adalah: penjual yaitu pemilik pohon mangga dan pembeli adalah tengkulak. Dalam hal ini sesuai dengan pasal 57 KHES yaitu pihak-pihak yang terikat dalam perjanjian jual beli adalah penjual, pembeli dan pihak lain yang terlibat dalam perjanjian jual beli tersebut.

Dalam obyek jual beli adalah berupa buah mangga yang masih diatas pohon dan besar kemungkinan masih dalam proses masak. Bentuk kesepakatan yang ada dalam praktik jual beli buah mangga dengan sistem tebas umumnya dalam bentuk lisan, bentuk tertulis ada pun biasanya berupa nota berapa harga dari buah mangga yang dibelinya. Hal ini sesuai

\footnotetext{
${ }^{5}$ Ahmad Sarwat, Fiqih Jual-Beli, vol. 6 (Lentera Islam, 2018).

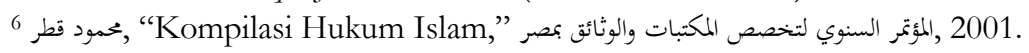


dengan Pasal 59 ayat (1) KHES. Berkaitan dengan rukun jual beli secara umum telah sesuai dengan kompilasi hukum ekonomi syariah. ${ }^{7}$

Berkaitan dengan pasal 65 KHES yang berbunyi: "Penjual boleh menawarkan penjualan barang dengan harga borongan dan persetujuan pembeli atas tawaran itu mengharuskannya untuk. membeli keseluruban barang dengan harga yang disepakati.”

Sistem borongan ini sesuai dengan sistem tebas akan tetapi tidak seluruhnya. Sistem borongan hanya berkaitan dengan sisi pengambilan barangnya saja sedangkan sistem tebas lebih luas hingga kapan waktu panen buahnya dilakukan.

Kemudian pada bentuk obyek jual beli pada pasal 76 KHES, praktik jual beli buah mangga dengan sistem tebas ini tidak terdapat permasalahan, namun jika masuk ke pasal 77 KHES yang berbunyi: “jual beli dapat dilakukan terbadap barang yang terukur menurut porsi, jumlab, berat atau panjang, baik berupa satuan atau keseluruban, barang yang ditakar atau ditimbang sesuai dengan jumlah yang telah ditentukan, sekalipun kapasitas dari takaran dan timbangan tidak diketahui, dan satuan komponen dari barang yang sudah dipisabkan dari komponen lain yang telah terjual."

Terdapat permasalahan yang muncul di dalamnya, yaitu buah mangga yang masih di atas pohon masih mengalami proses masak yang kemudian telah diperkirakan harga jualnya oleh penjual dan telah disepakati oleh pembeli, maka buah yang masih ada diatas pohon bukanlah barang yang terhitung menurut jumlah dan beratnya.

Dalam hal penyerahan barang kepada tengkulak dalam praktik ini yang mana panen dilakukan ketika buah sudah dirasa masak oleh tengkulak namun tidak bertepatan dengan penyerahan uang kepada penjual buah mangga dan akibat dari proses masak di atas pohon yang memungkinkan terdapat rusaknya buah mangga yang disebabkan oleh siklus alam seperti angin yang mengakibatkan buah mangga jatuh, hewan yang membuat buah mangga rusak dan faktor lainnya yang menjadikan buah mangga rusak maka buah mangga tersebut menjadi tanggungan tengkulak, dan tengkulak dalam hal ini dirugikan, maka hal ini tidak sesuai dengan pasal 87 yang berbunyi: "apabila barang yang dijual itu rusake ketika masih berada pada tanggungan penjual sebelum diserabkan kepada pembeli, harta tersebut masih harta milik penjual dan kerugian itu ditanggung oleh penjual."

Maka konsekuensi dari kasus diatas adalah bahwa bentuk konsekuensi yang diakibatkan dari rusak atau hilangnya barang yang

\footnotetext{
7 Abdul Mughits, "Kompilasi Hukum Ekonomi Syari'ah (KHES) Dalam Tinjauan Hukum Islam," Al-Mawarid, 2008, https://doi.org/10.20885/almawarid.vol18.art1.

${ }^{8}$ Nashihul Ibad Elhas, "Kompilasi Hukum Ekonomi Syariah: Tinjauan Umum Hukum Islam,” Jurnal Studi Islam : Qolamuna, 2016.
} 
belum diserahkan kepada pembeli seperti halnya buah yang masih di atas pohon haruslah menjadi tanggungan penjual.

\section{Akad Dalam Jual Beli}

Salam (In Front Payment Sale), secara terminologis adalah transaksi terhadap barang yang dijelaskan sifatnya dalam tanggungan dalam suatu tempo dengan harga yang diberikan kontan di tempat transaksi. Menurut kompilasi hukum ekonomi syariah, salam adalah pembiayaan yang berkaitan dengan jual beli yang pembiayaannya dilakukan secara bersamaan dengan pemesanan barang. Terdapat rukun dan syarat yaitu, shigat (ijab qobul), 'aqidain (dua orang yang melakukan transaksi), objek transaksi (harga dan barang yang dipesan).

Syarat-syarat dalam salam pertama, pembayaran dilakukan terlebih dahulu ditempat akad. Kedua, barang menjadi untang bagi pejual. Ketiga barang dapat diberikan sesuai waktu yang disepakati. Keempat, barang tersebut jelas bentuk, ukuran, dan jumlanya. Kelima, mengetahui dan mneyebutkan sifat dan macam barangnya dengan jelas. Keenam, disebutkan tempat menerimanya. ${ }^{9}$

Menurut kompilasi hukum ekonomi syariah pasal $101 \mathrm{~s} / \mathrm{d}$ pasal 103, bahwa syarat ba'i salam adalah sebagai berikut: pertama, kualitas dan kuatitas harus jelas. Kedua, spesifikasi barang yang dipesan harus diketahui secara sepurna oleh para pihak. Ketiga, barang yang dijual, waktu, dan tempat penyerahan jelas. Keempat, pembayaran barang dapat dilakukan pada waktu dan tempat yang disepakati.

Dasar hukum salam, QS. Al-Baqarah (2) ayat 282 sebagai berikut: "Hai orang-orang yang beriman, apabila kamu bermuamalah tidak secara tunai untuk waktu yang ditentukan, hendaklah kalian menuliskannya". Didalam alhadis sebagai berikut: "Ibnu Abbas meriwayatkan, babwa Rasulullab SAW datang ke Madinah dimana penduduknya melakukan salaf (salam) dalam buahbuaban (untuk jangka waktu) satu, dua, dan tiga tabun. Beliau berkata "barangsiapa yang melakukan salaf (salam), bendaklah ia melakukan dengan takaran yang jelas dan timbangan yang jelas pula, untuk jangka waktu yang ditentukan." dalam hadis lain: "dari Shihab r.a bahwa Rasulullah SAW bersabda: "tiga hal yang didalamnya terdapat keberakahan: jual beli secara tangguh, muqaradhah (mudarabah), dan mencampur gandum dengan tepung untuk keperluan rumah, bukan untuk dijual.”(HR. Ibnu Majah)

Perbedaan ba'i al-salam dengan ijon, kebanyakan dari orang awam menyamakan jual beli ijon dengan ba'i al-salam. Dalam ijon, barang yang dibeli tidak diukur atau ditimbang secara jelas dan spesifik. Dengan demikian juga penetapan harga beli, sangat bergantung kepada keputusan

${ }^{9}$ Dr Mardani, Fiqh Ekonomi Syariah: Fiqh Muamalah (Prenada Media, 2015). 
pihak tengkulak yang dominan dan menekan petani yang posisinya lebih lemah. Adapun keharusan transaksi ba'i al-salam yaitu: pertama, pengukuran dan spesifikasi yang jelas. Hal ini terdapat dalam hadis Rasulullah SAW yang diriwayatkan Ibnu Abbas, "Barang siapa melakukan transaksi salaf (salam), hendaklah dia melakukan dengan takaran yang jelas, timbangan yang jelas, untuk jangka waktu yang jelas pula." Kedua, adanya keridhaan antara kedua belah pihak terutama dalam menyepakati harga. Allah SWT berfirman..."kecuali dengan jalan perniagaan yang berlaku dengan suka sama suka antara kalian ..."

Istishna' (Jual Beli dengan Pesanan), secara etismologi adalah masdar dari sitashna 'asy-sya'i, artinya meminta membantu sesuatu. Adapun istishna' secara terminologis adalah transaksi terhadap barang dagangan dalam tanggungan yang disyaratkan untuk menjalankan. Menurut kompilasi hukum ekonomi syariah, istishna' adalah jual beli barang atau jasa dalam bentuk pemesanan dengan kriteria dan pensyaratan tertentu yang disepakati antara pihak pemesan dan pihak penjual. $^{10}$

Perbedaan istishna' dengan salam, dalam bertransaksi jika ditinjau dari segi objek (barang) menyerupai jual beli salam. Istishna' merupakan salah satu bentuk dari jual beli salam, istishna' didefinisikan dengan kontrak penjualan antara pembeli dan pembuat barang. Menurut Jumhur Fukaha, ba'i istishna' merupakan ciri khas dari akad ba'i salam. Bedanya, istishna' digunakan dalam bidang manufaktur. Dengan demikian, ketentuan ba'i istishna' mengikuti ketentuan atau atauran akad ba'i salam.

Perbedaan istishna' dengan ijarah, dalam bertransaksi istishna' semua barang yang akan dibuat dan dipekerjakan menjadi kewajiban shani (pembuat/pekerja). Sedangkan dalam ijarah, barang yang dikerjakan harus dari pembeli dan penjual hanya diminta mengerjakannya.

Syarat dan rukun istishna', menurut pasal $104 \mathrm{~s} / \mathrm{d}$ pasal 108 kompilsi hukum ekonomi syariah adalah: pertama, ba'i istishna' mengikat setelah masing-masing pihak sepakat atas barang yang dipesan. Kedua, ba'i istishna' dilakukan pada barang yang bisa dipesan. Ketiga, dalam ba'i istishna', identifikasi dan deskripsi barang yang dijual sesuai permintaan pemesanan. Keempat, pembayaran ba'i istishna dilakukan pada waktu dan tempat yang disepakati. Kelima, setelah melakukan akad jual beli jika pesanan bertambah, maka tidak satupun boleh tawar-menawar kembali terhadap isi akad yang sudah disepakati. Keenam, jika barang tidak sesuai spesifikasi maka pemesanan dapat menggunakan hak pilihan (khiyar) untuk melanjutkan atau membatalkan pesanan.

\footnotetext{
${ }^{10}$ Mardani.
} 
Adapun rukun istishna' sebagai berikut: pertama, al-'aqidain (dua pihak yang melakukan transaksi) harus mempunyai hak membelanjakan harta. Kedua (shighat), yaitu segala sesuatu yang menunjukkan aspek suka sama suka dari kedua belah pihak, yaitu penjual dan pembeli. Objek yang ditransaksikan, yaitu barang produksi.

Dasar hukum Istishna', pendapat ulama yang memperbolehkan transaksi istishna'. Bahwa syarat istishna' berdasarkan sunnah Nabi Muhammad SAW. Pada saat beliau minta dibuatkan cincin sebagaimana yang diriwayatkan Imam Bukhari, sebagai berikut: "Dari Ibnu Umar r.a, bahwa Rasulullah SAW minta dibuatkan cincin dari emas. Beliau memakainya dan meletakkan batu mata cincin di bagian dalam telapak tangan. Orang-orang pun membuat cincin. Kemudian beliau duduk di atas mimbar, melepas cincinnya, dan bersabda, "seseungguhnya aku tadinya memakai cincin ini dan aku letakkan batu mata cincin ini di bagian dalam telapak tangan". Kemudian beliau membuang cincinya dan bersabda, "Demi Allah, aku tidak akan memakainya selamanya". Kemudia orang-orang membuang cincin mereka" (HR. Bukhari)

Ibnu al-Atsir menyatakan bahwa maksudnya beliau meminta dibuatkan cincin untuknya. Al-Kaisani dalam kitab bada'iu ash-shana'i menyatakan bahwa istishna' telah menjadi ijma' sejak zaman Rasulullah SAW tanpa ada yang merangkul. Kaum muslimin telah mempraktikkan transaksi seperti ini, karena memang sangat dibutuhkan. ${ }^{11}$

Murabahah (Deferred Payment Sale), disebut juga ba'bitsmanil ajil. Kata murabahah berasal dari kata ribhu (keuntungan). Arti murabahah adalah saling menguntungkan. Secara singkat bahwa murabahah berarti jual beli barang ditambah dengan keuntungan yang disepakati. Secara terminologis murabahah adalah pembiayaan yang saling menguntungkan dan dilakukan oleh shabib al-mal dengan pihak yang melakukan transaksi jual beli dengan penjelasan bahwa harga pengadaan barang dan harga jual terdapat keuntungan atau laba bagi shabib al-mal dan pengembaliannya dilakukan secara tunai atau angsur. Akad ini merupakan salah satu bentuk natural certainty contracts, karena dalam murabahah ditentukan beberapa required rate profit (keuntungan yang ingin diperoleh).

Dasar hukum murabahah adalah suatu jual beli yang dibenarkan oleh syariah dan merupakan implementasi muamalah tijariyah (interaski bisnis). Berdasarkan Q.S Al-Baqarah (2): 275 "Allab menghalalkan jual beli dan mengharamkan riba"

Syarat dan rukun murabahah, adapaun syarat yang harus dipenuhi dalam transaksi murababah: pertama, jual beli murababah harus dilakukan atas barang yang dimiliki (hak kepemilikian sudah berada ditangan si

\footnotetext{
${ }^{11}$ Mardani.
} 
penjual). Kedua, adanya kejelasan informasi mengenai besarnya modal dan biaya lain yang biasa dikeluarkan dalam jual beli pada suatu barang dagang serta harus diketahui oleh pembeli pada saat bertransaksi. Ketiga, adanya informasi keuntungan baik nomimal maupun persentase yang diketahui pembeli sebagai salah satu syarat sah murabahah. Keempat, dalam system murabahah penjual boleh menetapkan syarat pada pembeli untuk menjamin kerusakan yang tidak tampak pada barang, tetapi lebih baik syarat seperti itu tidak ditetapkan, karena pengawasan barang merupakan kewajiban penjual utuk menjaga kepercayaan yang sebaikbaiknya. ${ }^{12}$

Perbedaan anatra salam, istishna', dan murabahah, merupakan pembiayaan berdasarkan akad jual beli. Murabahah merupakan jual beli dimana barangnya sudah ada, sedangkan salam dan istishna' adalah jual beli dengan pemesanan terlebih dahulu.

\section{Macam Macam dan Khiyar dalam Jual Beli}

Secara bahasa al-khiyar berarti pilihan. Secara terminologis khiyar adalah hak pilih bagi salah satu atau kedua belah pihak yang melakukan transaksi untuk melangsungkan atau membatalkan transaksi yang disepakati sesuai dengan keadaan dari masing-masing pihak atau sebab faktor tertantu. Hikmah diperbolehkan khiyar dalam jual beli bertujuan untuk melindungi dari para pihak yang melakukan kerugian. Sehingga tujuan kemaslahahtan dalam akad jual beli tersebut bisa tercapai dengan baik dan saling meridhoi antara penjual dan pembeli. ${ }^{13}$

Pembagian kbiyar, dalam penggolongan khiyar ada perselisihan pendapat dari beberapa para ulama, diantaranya: menurut Hanafiyah dalam kutipan Rahmat Syafi dari kitab rad al-mukhtar, bahwa jumlah khiyar ada 17 macam. Menurut Malikiyah ada 2 macam yaitu, pertama, khiyar at-ta'ammul (meneliti, melihat), yaitu khiyar secara mutlak. Kedua, khiyar naqish (kurang), yakni apabila terdapat kekurangan pada barang yang dijual (khiyar al-hukum), maka khiyarnya menjadi batal. Menurut syafi'iyah ada 2 macam yaitu, pertama, at-tasybir yaitu khiyar yang menyebabkan pembeli memperlama transaksi sesuai dengan kehendaknya terhadap barang, baik dalam majlis maupun syarat. Kedua, khiyar naqishah disebabkan karena adanya pergantian. Perbedaan dalam lafadz atau adanya kesalahan dalam perbuatan. Dan menurut syara itu ada 16 macam, yang bisa diketahui hanya ada 3 macam. ${ }^{14}$

\footnotetext{
12 Mardani.

${ }^{13}$ M H Harun, Fiqh Muamalah (Muhammadiyah University Press, 2007).

${ }^{14}$ Dewi Sri Indriati, "Penerapan Khiyar Dalam Jual Beli," Jurnal Ilmiah Al-Syir'ah 2, no. 2 (2016).
} 
Macam macam khiyar, dilihat dari segi pihak yang melakukan akad jual beli, ada khiyar syarat, dan khiyar ta'yin. Dilihat dari segi sumber dari syara: ada khiyar 'aib, khiyar majelis, dan khiyar m'yah. Menurut Syaid Sabiq penulis kitab fiqh al-sunnah, membagi khiyar menjadi 3 macam yaitu: pertama, kbiyas majlis, yaitu hak milik yang dilakukan oleh kedua belah pihak masih berada pada tempat melakukan akad jual beli. Hal ini didasarkan kepada hadis Rasulullah SAW:

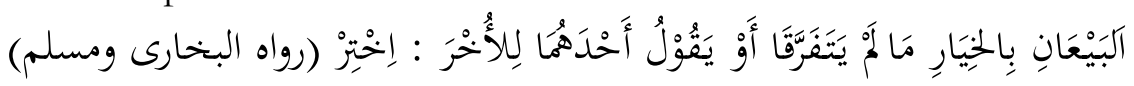

'Dua orang yang berjual beli dapat melakukan (perjanjian) khiyar selama mereka belum berpisah, atau salah satunya mengatakan kepada yang lain: piliblab" (H.R. Bukhari Muslim).

Kedua, khiyar syarat adalah hak memilih antara penjual dan pembeli yang disepakati dalam jangka waktu tertentu. Dalam jangka waktu tersebut, mereka boleh membatalkan atau melanjutkan jual beli. Adapun dasar syarat hukum khiyar yang diriwayatkan oleh Ibnu Umar bahwa Rasulullah bersabda: "Setiap dua orang yang melakukan transaksi jual beli, belum berlaku akadnya hingga mereka berpisah kecuali jual beli dengan khiyar" apabila jangka waktu yang ditentukan sudah berkahir dan akad tidak dibatalkan, maka jual beli telah sah. Ketiga, khiyar 'aib adalah hak pilih bagi pembeli untuk meneruskan atau membatalkan akad jual beli karena adanya cacat pada barang yang diperjualbelikan. Dasar hukum disyari'atkannya khiyar aib yang diriwayatkan oleh imam Ahmad, Ibnu Majah, ad-Daruqutni, alHakim dan at-Thabrani dari Uqbah bin Amir r.a.:

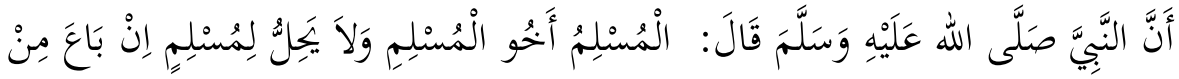

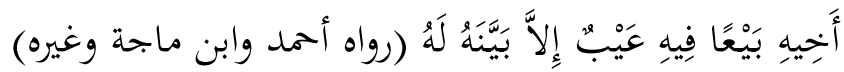

"Babwasanya Nabi SAW bersabda: muslim yang satu dengan muslim lainnya adalah bersaudara, tidak halal bagi seorang muslim menjual barangnya kepada muslim lain, padahal pada barang tersebut terdapat aib/cacat melainkan dia barus menjelaskannya". (HR. Ahmad, Ibnu Majah, Ad-Daraquthni, Al-Hakim dan AthThabrani)

\section{Jual Beli Tebasan (Jizaf)}

Dalam Kamus Besar Bahasa Indonesia (KBBI) pengertian jual beli adalah persetujuan antara penjual dan pembeli yang saling mengikat. 
Sedangkan borongan diartikan: borongan/bo'rong/verb melakukan pembelian secara besar-besaran. ${ }^{15}$

Sedangkan dalam ilmu fiqh borongan dalam ilmu jual beli disebut dengan al-jizaf yang artinya jual beli barang tanpa ditimbang, ditakar atau dihitung. Secara bahasa jizaf artinya mengambil dalam jumlah banyak, menurut Imam Syaukani, al-jizaf merupakan sesuatu yang tidak diketahui kuantitasnya secara detail.

\section{Syarat dan Jual Beli Tebasan (Jizaf)}

Sebagaimana pendapat para fuqaha Malikiyah dan ulama lain dalam (Al-Mausa'ah Al-Fiqhiyah, juz 9: 73-76), mensyaratkan 6 syarat sah jual beli jizaf, yaitu:

Obyek transaksi harus nyata dan dapat dilihat oleh mata kepala ketika sedang melakukan akad baik sesudah maupun sebelum. Dan para Ulam Hanafiyah, Syafiiyah dan Hanabilah setuju dengan syarat tersebut. Serta dapat menghilangkan gharar jahalah (ketidaktahuan obyek) dapat dihilangkan.

Pejual dan pembeli tidak mengetahui secara jelas kualitas barang dalam jual beli, baik dari segi ukuran, timbangan, dan hitunganya. Imam Ahmad menyatakan, jika seorang penjual mengetahui kualitas obyek transaksi, maka penjual tidak perlu menjual secara jizaf. Namun, jika penjual tetap menjual secara jizaf dengan penjual mengetahui kondisi atau kualitas obyek transaksi, maka transaksi jual beli dianggap sah dan bersifat lazim, namun menjadi makruh tanæih.

Jual beli yang dilakukan atas dasar sesuatu yang dibeli secara tebasan atau borongan, bukan per satuan. Akad jizaf diperbolehkan untuk sesuatu barang yang bisa ditakar atau ditimbang, seperti biji-bijian dan sejenisnya. Jual beli jizaf tidak bisa dibuat untuk pakaian, kendaraan yang dapat dinilai persatuannya. Berbeda dengan barang yang nilainya sangat kecil persatuannya, atau memiliki bentuk yang relatif sama. Seperti telor, apel, mangga, semangka, kurma dan sejenisnya. Jika obyek transaksi bisa dihitung tanpa adanya upaya yang melelahkan dan rumit, maka tidak boleh ditransaksikan secara jizaf, dan juga sebaliknya.

Obyek transaksi bisa ditaksir oleh orang yang memiliki keahlian dalam penaksiran. Akad jizaf tidak bisa dipraktikkan pada obyek yang sulit untuk ditaksir. Madzhab Syafiiyyah setuju dengan adanya syarat ini, mereka menetapkan bahwa kadar shubroh (kumpulan makanan tanpa ada

15 Juju Jumena, A. Otong Busthomi, and Husnul Khotimah, "JUAL BELI BORONGAN BAWANG MERAH DI DESA GRINTING MENURUT TINJAUAN HUKUM ISLAM," Al-Mustashfa: Jurnal Penelitian Hukum Ekonomi Syariah, 2017, 
timbangan dan takarannya) harus bisa diketahui, walaupun dengan cara menaksir. Serta obyek akad jumlahnya harus banyak.

Tanah yang digunakan sebagai tempat penimbunan obyek transaksi haruslah rata, sehingga kualitas obyek transaksi bisa ditaksir. Jika tanah dalam kondisi menggunung atau landai, maka kemungkinan kualitas obyek transaksi bisa berbeda misalnya kacang tanah. Jika ternyata tanah dalam kondisi tidak rata, maka keduanya memiliki hak khiyar.

Tidak diperbolehkan mengumpulkan jual beli barang yang tidak diketahui kualitasnya secara jelas, dengan barang yang kualitasnya diketahui secara jelas dalam satu akad. Misalnya, jual beli kurma satu kilo, dikumpulkan dengan apel yang berada dalam satu pohon, dengan satu harga atau dua harga. ${ }^{16}$

\section{Dasar Hukum Jual Beli Tebasan (Jizaf)}

Hadist yang diriwayatkan oleh Bukhori Muslim:

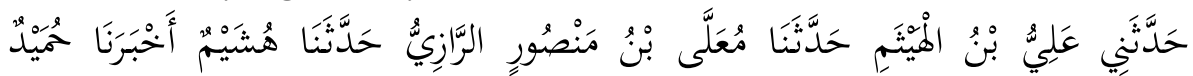

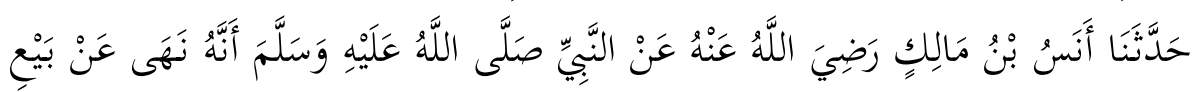

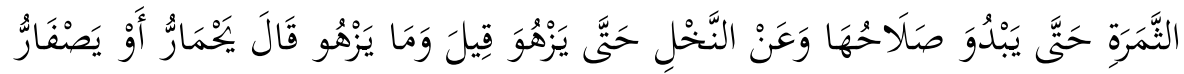

'Telah menceritakan kepadaku 'Ali bin Al Haitsam telah menceritakan kepada kami Mu'allaa bin Manshur Ar-Raziy telab menceritakan kepada kami Husyaim telab mengabarkan kepada kami Humaid telah menceritakan kepada kami Anas bin Malik. radliallabu 'anbu dari Nabi shallallabu 'alaibi wasallam babwa Beliau melarang menjual buah-buahan hingga jelas kebaikan dan (melarang pula menjual) kurma binga sempurna. Ada yang bertanya; "apa tanda sempurnanya?" beliau menjawab: "ia menjadi merah atau kuning". ${ }^{17}$

Hadits yang diriwayatkan oleh Imam Muslim dari Jabir Radhiyallahu anhu:
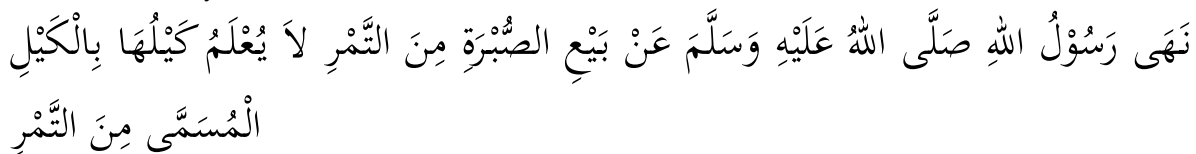

16 Abdul Kholiq Syafa'at and Rohmatulloh Rohmatulloh, "Analisis Hukum Islam Terhadap Praktik Jual Beli Hasil Pertanian Padi Sistem Tebasan Di Dusun Kelir Desa Bunder Kecamatan Kabat Kabupaten Banyuwangi," Jurnal Darussalam: Jurnal Pendidikan, Komunikasi Dan Pemikiran Hukum Islam, 2018,

${ }^{17}$ Syafa'at and Rohmatulloh. 


\section{"Rasulullab Shallallahu 'alaibi wa sallam melarang menjual setumpukan kurma yang belum diketabui timbangannya dengan kurma yang sudah diketabui timbangannya."}

Dalam hadits ini dijelaskan tentang bolehnya menjual kurma tanpa ditimbang terlebih dahulu jika harganya berupa uang, tetapi jika harga kurma tersebut berupa kurma yang sama, maka akad dalam jual belinya menjadi haram karena terdapat unsur riba fadhl, sebab kurma termasuk ashnaf ribawiyyah (barang-barang yang rentan terdapat unsur riba) dalam hukum jual beli. Contohnya seperti menjual emas dengan emas atau menjual perak dengan perak ataupun yang lainnya dari barang-barang yang sering terdapat unsur riba, maka tidak boleh menjual barang-barang tersebut dengan barang yang sejenis dengannya tanpa ditakar dan ditimbang terlebih dahulu karena dikhawatirkan adanya tambahan atau kelebihan pada salah satu dari dua barang tersebut yang tidak ada didalam salah satunya.

Jama'ah (imam hadits) kecuali at-Tirmidzi dan Ibnu Majah meriwayatkan dari Ibnu 'Umar Radhiyallahu anhuma, berkata:

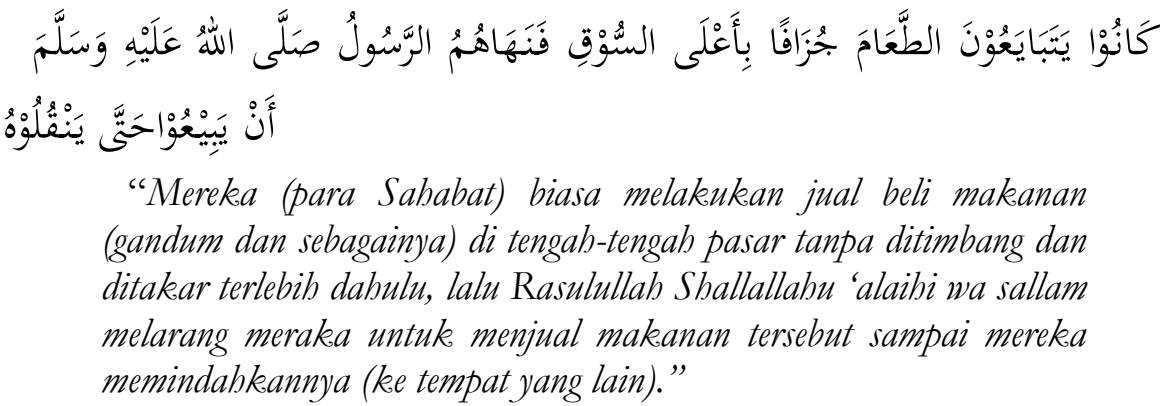

Dalam hadits ini terdapat dalil bolehnya jual beli barang tanpa ditimbang dan ditakar terlebih dahulu karena Nabi Shallallahu 'alaihi wa sallam menetapkan para sahabat melakukan jual beli yang demikian, namun beliau melarang para sahabat dari sesuatu jual beli yang sudah dibeli sebelum para sahabat menerimanya.

Ibnu Qudamah berkata, "Boleh melakukan jual beli setumpukan barang tanpa ditimbang dan tanpa ditakar terlebih dabulu, dan kami tidak mengetahui adanya kbilaf (perbedaan pendapat) dalam masalah 


\section{ini walaupun penjual dan pembeli tidak mengetabui kadarnya secara pasti." 18}

Kesimpulan dari kedua hadits diatas bahwasanya jual beli jizaf itu diperbolehkan asalkan memenuhi syarat yang sudah ditetapkan.

\section{Pemaparan Transaksi Dengan Sistem Tebas}

Dalam tahap pembahasan ini penulis akan memaparkan tentang transaksi muamalah pada pembelian buah manga dengan sistem "tebas". Sistem tebas yang dikenal di dalam masyarakat yaitu berkaitan dengan pembelian buah yang mana buah tersebut masih dalam proses masak di atas pohon, kemudian pembeli (tengkulak), memberi penawaran kepada pemilik pohon mangga yang berbuah tersebut. Dari hasil tawar menawar yang dilakukan antara pemilik pohon mangga dengan tengkulak yang menawar buah mangga yang masih di atas pohon tadi maka terjadilah kesepakatan antara keduanya. Buah mangga bisa di panen seketika tawar menawar antara pemilik pohon mangga dengan tengkulak. Penentuan harga yang ditawarkan oleh tengkulak umumnya hanya sebuah perkiraan yang dilakukan oleh tengkulak, bentuk perkiraan menggunakan dasar banyaknya jumlah buah mangga yang ada di atas pohon, akan tetapi tengkulak dalam melakukan perkiraan jumlah buah yang ada di atas pohon tidak secara rinci menghitung jumlahnya, hanya sekedar dilihat dengan sekilas buah mangga yang ada di pohon mangga tersebut kemudian menentukan harganya, dan jika terjadi kesepakatan antara tengkulak dengan pemilik pohon maka akad jual belipun telah terbentuk. Dalam hal panen, terdapat dua kondisi yaitu, pertama tengkulak menunggu beberapa hari hingga terdapat buah mangga yang akan lebih masak, kedua tengkulak langsung memanen buah mangga yang sekiranya oleh tengkulak sudah bisa dipanen.

\section{PENUTUP}

Dalam hal muamalah yang merupakan hubungan pemenuhan kebutuhan antara manusia dengan manusia lainnya, dalam konteks jual beli, menurut syariat agama Islam diperbolehkan. Pembolehan di dalam syariat Islam termaktub dalam al-Qur'an surat al-Baqarah ayat 275 , serta di dalam hadis yang diriwayatkan oleh al-Bazzar dan al-Hakim.

Sistem tebas yang dikenal di dalam masyarakat yaitu berkaitan dengan pembelian buah yang mana buah tersebut masih dalam proses

18 https://almanhaj.or.id/4034-jual-beli-jazaf-tanpa-ditimbang-atau-ditakar-menjualhutang-dengan-hutang.html diakses pada selasa 10 november 2020 pukul 00.40 
masak di atas pohon, kemudian pembeli (tengkulak), memberi penawaran kepada pemilik pohon mangga yang berbuah tersebut. Dari hasil tawar menawar yang dilakukan antara pemilik pohon mangga dengan tengkulak yang menawar buah mangga yang masih di atas pohon tadi maka terjadilah kesepakatan antara keduanya.

Jika dilihat dari pembahasan di atas dapat ditarik kesimpulan bahwa terdapat sisi yang telah sesuai dengan kompilasi hukum ekonomi syariah yang pertama rukun yang telah terpenuhi yaitu pihak-pihak yang melakukan transaksi dalam hal ini adalah penjual buah mangga yang masih diatas pohon, kemudian pembeli dalam hal ini adalah tengkulak. Kedua dalam hal obyek yang diperjual belikan adalah buah mangga yang kondisinya masih dalam proses masak di atas pohon. Ketiga adanya kesepakatan antara penjual dan pembeli yang mana kesepakatannya adalah tengkulak menawarkan harga beli yang sesuai dengan perkiraan tengkulak hanya dengan melihat sekilas buah mangga yang ada di atas pohon kemudian penjual menyepakatinya, kemudian tengkulak akan memanen pohon dengan menunggu proses masak di atas pohon, sekiranya telah cukup proses masak, maka tengkulak memanen buah mangga tersebut. Dalam ketiga hal di telah tercukupi rukunnya dan sesuai deng KHES.

Akan tetapi terdapat permasalahan dalam praktik diatas dan tidak sesuai dengan yang telah diatur di dalam KHES. Pertama, buah mangga yang masih di atas pohon masih mengalami proses masak yang kemudian telah diperkirakan harga jualnya oleh penjual dan telah disepakati oleh pembeli, maka buah yang masih ada diatas pohon bukanlah barang yang terukur menurut jumlah dan beratnya, Hal ini tidak sesuai dengan pasal 77 KHES. Kedua, tanggungan yang dibebankan kepada tengkulak akibat dari rusaknya buah yang masih di atas pohon tidak sesuai dengan pasal 87 KHES, yang seharusnya ketika barang belum diserahkan kepada pembeli dalam hal ini tengkulak, dan akad telah terbentuk, maka barang masih menjadi tanggungan penjual buah.

\section{DAFTAR PUSTAKA}

Ghazaly, Abdul Rahman, Ghufron Ihsan, and Sapiudin Shidiq. Fiqh Muamalat. Jakarta: Fakultas Ilmu Tarbiyah dan Keguruan UIN Syarif Hidayatullah, 2016, 2016.

Harun, M H. Fiqh Muamalah. Muhammadiyah University Press, 2007.

Indriati, Dewi Sri. "Penerapan Khiyar Dalam Jual Beli." Jurnal Ilmiah AlSyir'ah 2, no. 2 (2016).

Jamaluddin, Jamaluddin. "Konsep Dasar Muamalah \& Etika Jual Beli (Al-Ba'i) Perspektif Islam." Jurnal Pemikiran Keislaman, 2017. 
https://doi.org/10.33367/tribakti.v28i2.485.

Jumena, Juju, A. Otong Busthomi, and Husnul Khotimah. "JUAL BELI BORONGAN BAWANG MERAH DI DESA GRINTING MENURUT TINJAUAN HUKUM ISLAM." Al-Mustashfa: Jurnal Penelitian Hukum Ekonomi Syariah, 2017. https://doi.org/10.24235/jm.v2i2.2155.

Kementerian Agama, RI. Al-Qur'an Terjemahan. Al-Qur'an Terjemahan, 2007.

Mardani, Dr. Fiqh Ekonomi Syariah: Fiqh Muamalah. Prenada Media, 2015. Mughits, Abdul. "Kompilasi Hukum Ekonomi Syari'ah (KHES) Dalam Tinjauan Hukum Islam." Al-Mawarid, 2008. https://doi.org/10.20885/almawarid.vol18.art1.

Nashihul Ibad Elhas. "Kompilasi Hukum Ekonomi Syariah: Tinjauan Umum Hukum Islam.” Jumal Studi Islam : Qolamuna, 2016.

Pudjiraharjo, M, and Nur Faizin Muhith. Fikih Muamalah Ekonomi Syariah. Universitas Brawijaya Press, 2019.

Sarwat, Ahmad. Fiqih Jual-Beli. Vol. 6. Lentera Islam, 2018.

Syafa'at, Abdul Kholiq, and Rohmatulloh Rohmatulloh. "Analisis Hukum Islam Terhadap Praktik Jual Beli Hasil Pertanian Padi Sistem Tebasan Di Dusun Kelir Desa Bunder Kecamatan Kabat Kabupaten Banyuwangi." Jurnal Darussalam: Jurnal Pendidikan, Komunikasi Dan Pemikiran Hukum Islam, 2018. https://doi.org/10.30739/darussalam.v10i1.277.

المؤتصر السنوي لتخصص المكتبات "Kompilasi Hukum Islam." .قطر, محمود

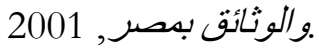

